\title{
READERS
}

Journal of Management Info (JMI)

ISSN:2313-3376

www.readersinsight.net/jmi

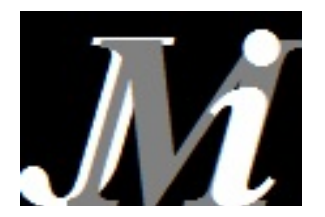

\section{Aesthetics of retailers: An evaluation of self-service, full service, and web-retailers}

\author{
Khurram Aziz \\ ${ }^{1}$ University of the Punjab, Gujranwala Campus. Pakistan \\ * Corresponding author: khurramaziz786@gmail.com
}

\begin{abstract}
Organizational aesthetics is a new area of organizational study and relates with a form of human knowledge which a person develops by using his five senses including hearing, sight, touch, taste, and smell. This knowledge of a person is associated with developing a perception about an organization, its purpose, main values, etc. Aesthetics shapes emotions, attitudes, and behavior of people. The aim of this research is to evaluate aesthetics of different service level of retailers of convenience products. Such evaluation of aesthetics of retailers based on service level would become the basis of evaluation of how each option generates value for the customers. Such knowledge will be useful for the organizational decision makers and they can use it to select/adjust service level with the desired level of value. In order to achieve the stated aim, a scientific research was carried out by the researchers. The researchers used case study research methods to analyze the dynamics of retail sales level in order to evaluate related aesthetics. The purpose was to evaluate, contrast and compare the aesthetics of different service levels (self-service, assortedservice, and full-service). The data collected during this research project was exclusively carried out for this research project only and was collected during the month of March 2016. Data was collected from different countries including United States of America and Pakistan. The findings of the research uncovered that style of three diverse retail benefit levels change in view of; design of retail outlet, comfort-related with each type of outlet, cleanliness, basic leadership process, impact of sales representatives, self-rule of purchaser in choosing items/administrations, cost of operations to retailer, speed of administration, assortment looking for conduct, music, sound and video in retail condition, capacity to counsel others, chance to feel items, level of instruction, chance to retailer of association and gaining from clients and shopping at claim speed. Retailers should choose their retailing technique (self-benefit retailing, full-benefit retailing and e-retailer) after a watchful investigation of these variables.
\end{abstract}

\section{ARTICLE INFORMATION}

\section{Received: August March 2017 \\ Revised: September 2017}

Accepted: November 2017

DOI:

http://dx.doi.org//10.31580/jmi.v16i1.74

\section{Introduction}

Strati (2015) highlights the emergence of organizational aesthetics (OA) as a new area of organizational study and suggested that it is a form of human knowledge which a person develops by using his/her five senses including hearing, sight, touch, taste, and smell. This knowledge of a person is associated with developing a perception about an organization, its purpose, main values, etc. Gagliardi (1990) and Witkin (1990) suggested that aesthetics shape emotions, attitudes, and behavior of people. OA, as a field of study, helps concerned people who put themselves within a broader social context. Pratt and Rafaeli (2006) emphasized in the study the use of organizational aesthetics and suggested that $\mathrm{OA}$ is an influential technique through which an organization can manipulate its image in the eyes of its stakeholders, including its customers and employees. OA is not merely associated with making workplace beautiful rather it can be used to manipulate organizational power over its stakeholders. According to Henley and Patrick (1977), an organization can use its physical space and related aesthetics to develop or alter thoughts and behaviors of employees and customers. The work of Lefebvre (1991) can be used to decipher planning, shaping, and execution of organizational space related to OA. Lefebvre (1991) identified three dimensions of organizational space, which are conceived space, perceived space and lived space. Conceived space is associated with planning and conceptualization of space by architects and managers for projecting the desired image whereas, perceived space is concerned with material artifacts and bodily gestures. The third type of space is lived space which is concerned with interpreting space and its related aspects by people who are present in it. If an organization intends to have a desired lived space then it should ensure that conceived space is right in the first hand.

Wan, Chen, and Yiu (2015) suggested that organizational image and reputation is a critical ingredient of organizational success. It is associated with feelings of buyers about the organization and its related aspects. One such factor which shapes buyers' perception about the organization, is the retailing strategy of the organization (Lin \& He, 2015). Therefore, it is the responsibility of organizational decision makers that they should develop and maintain such retailing strategy so that customers receive requisite value from the organization. In this regard, efforts should be made to develop a quality image of the organization and its products and services. One such area from where an organization can provide value to its customers is a point-of-sales arrangement made by the organization (Broyles, Ross, Davis, \& Leingpibul, 2011). A strong retail arrangement can become a source of competitive advantage for the organization. Referring to Lefebvre (1991), the organization should 
make all possible attempts to ensure that lived space of the organization match with conceived space and one such area is through retailing strategy of the organization. Wong and Sohal (2003) highlighted that there are different retailers based on their service levels which are self-service, assorted service, and full service. Naylor and Frank (2000) suggested that customers drive different level of value from self-service, assorted service, and full-service retailers. In the last few years, considerable research has been carried out in the area of organizational aesthetics (Dzidowski, 2015; McLeod \& Guillemin, 2016; Strati, 2015; Taylor, 2016; Wasserman \& Frenkel, 2015). Most of this research has explored the employees' perspective of OA. However, there is a need for evaluation of $\mathrm{OA}$ from customers' value perspective. Different researchers have studied OA in different forms. For example, Witkin (1990) used the corporate spatial design for analysis of OA whereas Hancock (2005) used an account of war graves and even bodies of employees. Further to this, Berg and Kreiner (1990) used corporate buildings as symbolic resources for deciphering OA. In case of this research, retail space and retail service level will be used to analyze OA. The aim of this research is to evaluate aesthetics of different service level of retailers of convenience products. Such an evaluation of aesthetics of retailers based on service level would become the basis of evaluation of how each option generates value for the customers. Such knowledge will be useful for the organizational decision makers and they can use it to select/adjust service level with the desired level of value. This is in line with the work of Hancock (2005) who suggested that organizational aesthetics can be used to develop an understanding of organizational interventions. He highlighted that organizational artifacts, use of technology, interaction with customers, etc. are all different forms of organizational aesthetics.

\section{Literature review}

\section{Organizational aesthetics}

Strati (2015) suggested that OA is a form of human knowledge which a person develops by using his five senses i.e., hearing, sight, touch, taste, and smell. Such knowledge shapes the perception of people about different aspects of the organization. Gagliardi (1990) and Witkin (1990) added that OA is linked with emotions, attitudes, and behavior of people. It is concerned with people and how they put themselves within a broader social context. Taylor and Hansen (2005) suggested that OA is relevant to different phenomena of organizations. Moreover, Taylor and Ladkin (2009) further suggested that Aesthetics involves the use of arts-based methods within the organizations which adds meaning to organizational life. Pratt and Rafaeli (2006) suggested that organizations could use OA to promote their image in the eyes of its stakeholders, including customers and employees. Such manipulation of OA may increase organizational power over its stakeholders. Henley and Patrick (1977) highlighted a particular dimension of OA and argued that an organization can use its physical space and related aesthetics to develop or alter thoughts and behaviors of employees and customers. An earlier work carried out by Lefebvre (1991) can be used to analyze planning, shaping, and execution of organizational space related to OA. According to Lefebvre (1991), there are three dimensions of organizational space including conceived space, perceived space and lived space. Conceived space is associated with planning and conceptualization of space by architects and managers for projecting the desired image whereas, perceived space is concerned with material artifacts and bodily gestures. The third type of space is lived space which is concerned with interpreting space and its related aspects by people who are present in it. If an organization intends to have a desired lived space, then it should ensure that conceived space is right in the first place.

Magala, Weggeman, Lammers, and Akkermans (2007) suggested that aesthetics influence different organizational interventions. However, there are still certain areas in which such intervention of aesthetics is not clear. Schön (1983) suggested that OA is generally attributed to architects of the organizations as they are ones who design physical space of the organization. However, OA is also under the control of managers as their policies and decisions also have an influence on overall OA. The decisions of managers about work processes in the operational core have an influence on aesthetics experience of the people. Moreover, Dickinson (2000) also argued that OA is an important area of the business management as it adds beauty to the organization. The style of managers and overall beauty of the organization are important determinants of organizational success therefore, it is important that managerial interventions should be directed towards creating a "feel good aesthetics". This would not only attract and encourage employees of the organization but at the same time, would have an influence on the customers of the organization. Both employees and customers in turn would give their loyalty and commitment to the organization. Dickinson (2000) further suggested that owing to the importance attached to OA, organizations should spend more money on beautifying organizations as compared to the money spent on advertisement. This would enhance OA which makes organizations more meaningful in broader social context. Furthermore, Hancock (2005) suggested that different types of artifacts which an organization uses, add to aesthetics of the organization. As these relics have a material shape so these can be formed and changed too with the goal that a specific significance or part of association can be advanced. From organization's point of view, OA and related artifacts are vehicles of expression of the organization as these create sensory conditions for the observers including customers and employees.

\section{Retailing and level of retail service}

Samli (2015) highlighted the importance of the retail strategy of the organization and suggested that store layout and visual merchandising are among some of the various factors which add to the uniqueness of the store and make it different from others. The internal décor and external building of the store depicts different things about the store as well as having an influence on the perception of the customers. The building of the retail store, marquees, walkways, entrances, doors, displays, colors, materials, etc. are among different factors which are linked with appearance and aesthetics of the organization. Turley and Chebat (2002) suggested that interior of the organization has an influence on the perception of the customers. Use of fixtures, displays, color, lighting, musing, scent, ceilings and floor, and related artifacts create an image of the retail space.

Cazzato, Leo, Spagnolo, and Distante (2014) suggested that there are different ways in which retailers attract customers towards their products. This includes offering products which are required by the customers, reduced prices, location, etc. One way through which an organization can attract more customers towards its products is the level of retail service. Wong and Sohal (2003) suggested that there are three types of retail services which are self-service, assorted-service and full-service options. In case of self-service, customers perform most or even all of the activities related to purchasing. $\mathrm{Hu}$ and $\mathrm{Li}$ (2012) suggested that customers have mixed response related to selfservice. Some customers consider self-service as a convenience whereas others don't. Self-service checkouts can be seen in the form of online purchasing, vending machines, self-checkouts, etc. Assorted service, the second option, is a very popular one and is used by the majority of the retailers (Macintosh \& Lockshin, 1997). In this option, retailers provide some services whereas there are some activities which are to be performed by the retailers. Such support services include point-of-sale transaction, packaging, delivery service, credit payment plans, etc. Telephone retailing, website and catalog retailing are among some of the options of assorted service (Long \& McMellon, 2004). Lastly, full-service retailers provide all types of services related to purchasing of a product. Such retailers perceive that their retailing option is the one which provides maximum value to the customers (Macintosh \& Lockshin, 1997).

\section{Factors influencing the form of point of sales retailing}


Lusch, Serpkenci, and Orvis (2015) suggested that there is a number of factors which are to be considered when designing a retail strategy. While deciding about retail-service level or overall retail layout, managers should keep associated factors in mind as these factors provide a different level of value or service to the customers. $\mathrm{Lu}$ and Seo (2015) suggested that layout of a retail outlet is a major factor which influences the preferences of the customers. Shoppers would have a high level of satisfaction if the layout of retail store permits shoppers' access to products, opportunity to look at products, and after evaluating they select such products. This could be the basis of competitive advantage for the retail store. Moreover, Wu, Lee, Fu, and Wang (2013) highlighted the case of website retailers which is a form of assorted retailers and suggested that customers prefer website retailers as these website retailers provide them a high level of convenience. Customers do not have to travel to the retail outlets and thus can save time and traveling cost. Likewise, online retailers offer timeless and location-less operations. Furthermore, in case of online retailers, customers can spend as much time as they want while making a purchase decision. According to Jie, Subramanian, Ning, and Edwards (2015), in case of e-retailing, customers could use the Internet for getting information about same or similar products offered by the competitors. This helps customers in making a more prudent purchase decision. Likewise, online retailers can use audio, video and multimedia options while making any purchase decision. Yildirim, Cagatay, Hidayetoglu, and Towers (2015) suggested that cleanliness of retail store is another important factor that retailers have to consider. Customers prefer to room around and purchase from a neat and clean retail store. If the store has good hygiene conditions then customers would feel nice and they may spend more time in the store. This increases the chances of advancement in sales of the organization as if customers would spend more time in the store so they are likely to purchase more. Lusch et al. (2015) highlighted different aspects of retail decision-making and suggested that there is mixed evidence regarding satisfaction of customers from different retail service level. Some customers want self-service retail options because in this option they are free to spend as much time as they want in making a purchase decision. This option does not compromise customers' autonomy. Moreover, salesmen cannot influence customers in making any purchase decision. On the contrary, some customers indicated that they are more satisfied if they receive any assistance from the salesmen. Such customers report that if they do not have information about a product, for example, a specialty product then customers contact the salesmen and seek their support. This adds convenience to the sales process. Jie et al. (2015) highlighted the case of variety seeking customers and suggested that such customers prefer website and phone retailers. The underlying reason is that it is easier for customers to check prices and attributes/features of products online or over the phone as compared to visiting different stores or asking different salesmen. Further to this, Škudiene, Everhart, Šlepikaite, and Reardon (2013) suggested that while selecting a retail service level, retailers keep the cost of operations in mind. Where self-benefit requires more space, fullbenefit retailing required greater venture to be made in staff. So, while making such decisions, a cost analysis should be carried out and should be used in conjunction with the desired level of value which is to be added by the retailer.

Kumar (2014) suggested that in case of full-service options, customers do not have many opportunities of interacting with fellow customers or other persons and seek guidance for making a purchase decision. In case of self-service retailing, customers can talk to the fellow customers. Moreover, in case of websites or online retailing, customers can read online reviews and get information about the products and services offered by the organization. The advancement in technology has made it possible for the customers that they can consult to the retailers in a synchronous manner while surfing a website. However, online retailing is not an option for everyone. It requires some basic literacy and knowledge of world-wide-web. Kumar (2014) also highlighted the demerits of online retailing and suggested that in case of online retailing, it is not possible for the customers that they can physically touch and feel the products. For this, they have to visit stores and obtain products from there. Foster and Resnick (2013) added to merits and demerits of different level of retail service level and suggested that in case of self-service retailing in a store, the speed of service is generally slow. However, if customers obtain the assistance of retailer or his staff then the transaction can be quickly processed. This would help customers in obtaining desired products quickly.

\section{Methodology}

In order to achieve the stated aim, a scientific research was carried out by the researchers. The selected research philosophy was interpretivism whereas selected research approach was inductive reasoning. Further to this, selected research strategy was a case study and time dimension was cross-sectional. Data was collected using observation and interviews. The researchers analyzed the dynamics of retail sales level in order to analyze related aesthetics. The purpose was to evaluate, contrast and compare the aesthetics of different service levels (self-service, assorted-service and full-service). The data collected was exclusively carried out for this research project only and was collected during the month of March 2016. Data was collected from different countries including United States of America and Pakistan. The product selected for the purpose of this research was convenience food products, which was further, refined to fruits and vegetables category. The researchers collected data by visiting different vegetable/fruit retail stores, websites, and catalogs which offer fruits and vegetables. Both of these techniques (interviews and observation) are favored over others as these are information-rich and give researchers opportunity to adjust as per the requirement of the situation. During the data collection process, retail service level, store layout, and related artifacts were observed as well as discussion with interviewees was carried out on similar issues. Researchers carried out interviews not only during the observation phase but also separate interviews were carried out. The average time spent by the researchers in retail stores, on websites or in browsing retail catalog was around 45 minutes. The reason for this long stay was to ensure that in-depth information could be collected by the researchers about the issue in hand. After visiting 4 retail stores, 5 websites and interviewing 8 people on the subject matter, researchers felt that their saturation point has arrived so further data was not collected. Data from four different organizations were mainly used in this research project. During the observation phase, 6 people were interviewed. These interviews were conducted from both customers as well as employees of the organization. The interviews which were followed by the observations, were partly structured whereas 2 full-structured interviews were carried by the researchers. Prior to these interviews, researchers informed interviewees about the purpose of the research so that interviewees can give an informed response. During the research, the researchers had the opportunity to take photographs of the retailers' outlets. This helped the researchers in recalling their observation. Likewise, the researchers also documented their discussion with interviewees in black and white. Both observation and interviews are supported by the interpretive as an adaptable and rich method for gathering data (Maxwell, 2012). Both data collection methods were carried out in real research setting which made it highly reliable source of the collection of information.

During the research process, high regard was given to research ethics. The data was collected from the respondents after informing respondents about the purpose of the research. Findings of the research were reported without any alterations. The researchers also tried their level best to keep his personal bias to the minimum level. No data was collected from the minors so there was no need to take approval from the parents of the respondents. During and after the research, the anonymity of the respondents was ensured. Findings were reported in a way that no one can trace any response to any particular respondent. Likewise, in order to hide the identity of the people in the pictures, their faces were blurred. Further to this, findings were reported in aggregation. In addition to this, respondents were not given any financial or another benefit for responding in a particular way. The purpose and findings of the research did not result 
in any emotional, physical or financial harm to any individual or organization.

\section{Findings and discussion}

The findings of this research reported that aesthetics of retail stores differed based on their layout. The layout of the full-service and self-service was different. In case of self-service layout, since customers of self-service retail outlets have to move around in the retail, considerable walking space was provided. This was not the case in case of full-service retailers. In case of full-service retailers, walking or moving space was kept only for the retailer. This can be seen in figure 1, 2, 3 and 4, which are given below.

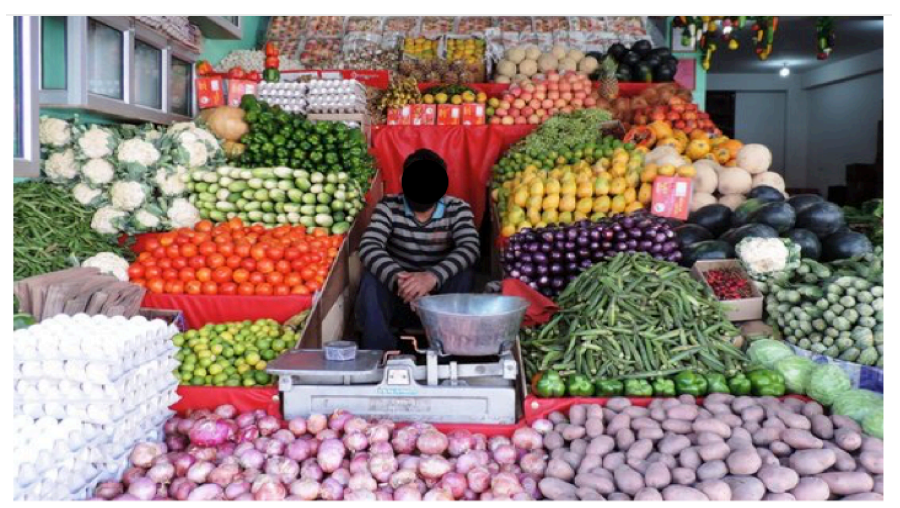

Fig. 1. Full-Service Retailer - 1

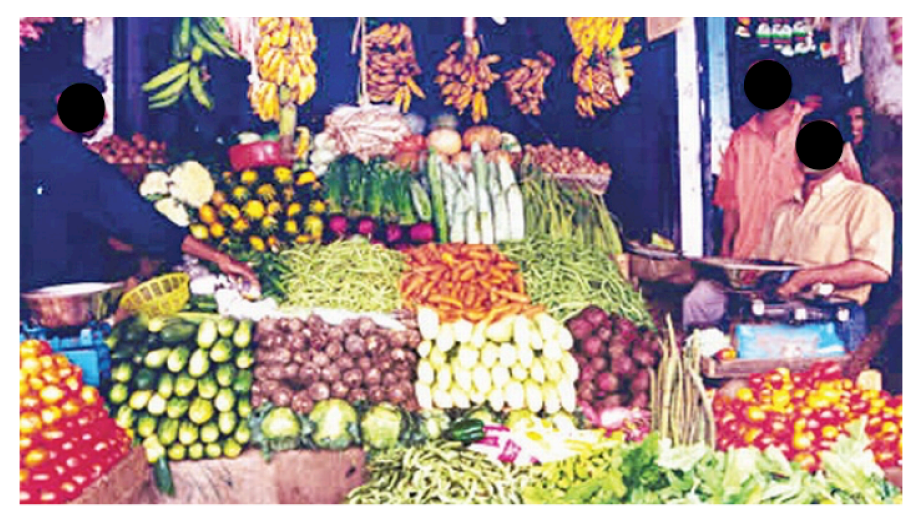

Fig. 2. Full-Service Retailer - 2

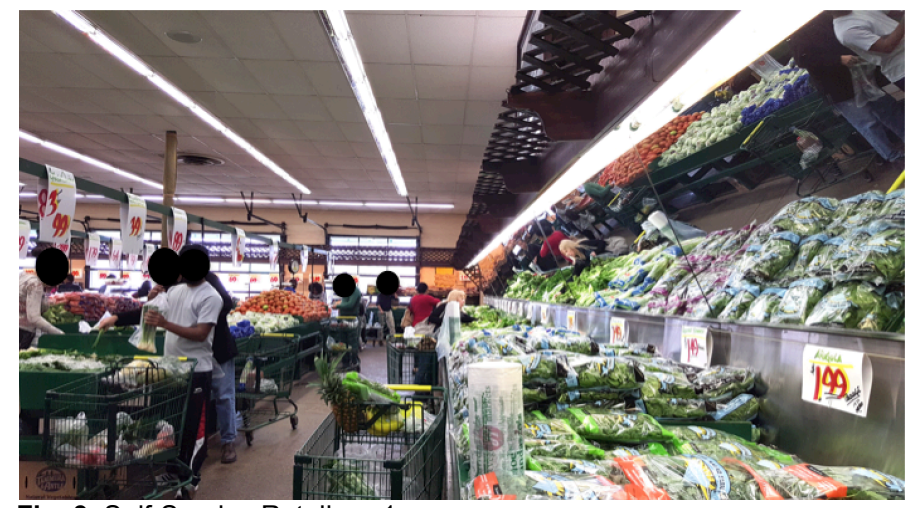

Fig. 3. Self-Service Retailer - 1

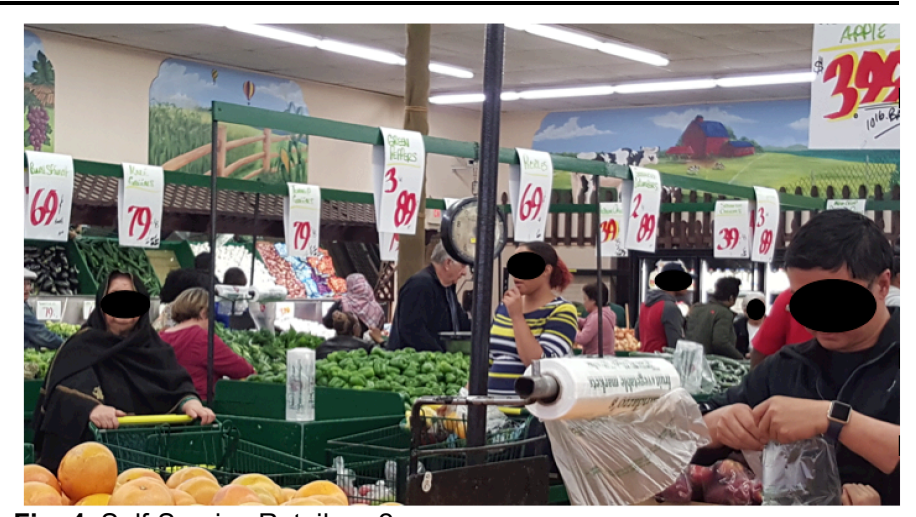

Fig. 4. Self-Service Retailer - 2

Figure 5 given below gives a picture of a website which offers vegetables online.

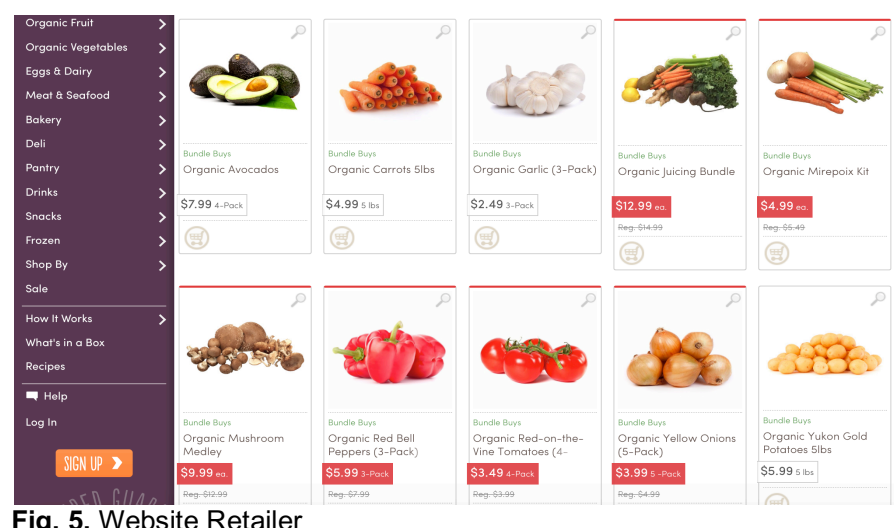

Figure 5 given above depicts the layout of website retailer.

Samli (2015) highlighted the importance of the retail strategy of the organization and suggested that store layout and visual merchandising are among some of the various factors which add to the uniqueness of the store and make it different from others. In case of figure 1 and 2, it can be seen that most of the vegetables are in the access of retailer. There was some space through which retailer can access vegetables. However, this was not the case in figure 3 and 4 . These figures are related to self-service retail level. One can observe that retail outlet was designed in a way that customers can move around in the retail store. The aesthetics of full-service layout gives an impression that retailer tends to give full support to the customers whereas aesthetics of self-service retailer is an indicator that retailer gives decisionmaking autonomy to the customers. Where in full-service retailing, retailer selects and gives vegetable and fruits to the customers. In case of self-service retailing, customers are free to choose any vegetable item from a pile of vegetables. Likewise, in case of full-service retailing, the speed of transaction depends on retailer whereas, in case of a self-service retailer, customers can purchase at their convenience. They can spend as much time as they can while purchasing an item from the retailer. This is also the case with web-retailer and catalog retailing. Same is the case with website retailer. This is shown in figure 5 .

The layout of the full-service retailer, self-service retailer and website retailer is both convenient as well as not convenient for the customers. In case of a full-service retailer, it is convenient for the customers as retailer carries out all the activities for the customers including selection and packaging of vegetables and fruits. On the contrary, in case of self-service retailing, customers have convenience in selecting fruit items. Same is the case with websites. In contrast to full-service and website retailing, in case of self-service retailing, customers have the opportunity of touching, smelling, tasting and looking at the actual product. These things add to the customers' perception about the aesthetics of organization in general and products (vegetables and 
fruits) in particular. Similar opportunities can be given to the customers yet in an electronic environment.

Further to this, cleanliness of the area which also adds to the aesthetics of the place, has a varying degree of influence in shaping the aesthetics sense of customers of vegetables in three forms of retail service level. Yildirim et al. (2015) suggested that cleanliness of retail store is another important factor that retailers have to consider. Customers prefer to room around and purchase from a neat and clean retail store. If the store has good hygiene conditions then customers would feel nice and they may spend more time in the store. In case of a self-service retailer, cleaning is strongly associated with the perception of the customers regarding overall aesthetics of the retailer. The underlying reason is that in case of self-service retailing, the customer has access to the area where vegetables and fruits are displayed. If that area was clean, the customer would be happy and vice versa. This is not the main issue in case of full-service retailing as in that case; it is the retailer who has to access the area where vegetables are placed. However, overall décor of the place should also be clean. In case of electronic retailing, cleanliness of the place is not an issue as customers are approaching retailer electronically and purchased items have to be sent to the customers via transport or customers may pick from a certain place.

Lusch et al. (2015) highlighted different aspects of retail decisionmaking and suggested that there is mixed evidence regarding satisfaction of customers from different retail service level. In case of full-service retailing, customers do not have much time for the transaction as retailers may have to serve other customers. However, this is not the case with self-service and website retailing. As figure 3 specifies, customers are free to move around in the store. They can talk to others and discuss the products (fruits and vegetables). Discussion may be related to taste, availability, size, price, etc. Similar opportunity is available to the customers who use electronic media to purchase vegetables and fruits. Like self-service retailing, they can discuss with friends, family members or others concerned during the decision-making process. In case of e-retailer, customers do have the opportunity to look at websites of competing retailers and then make a final decision. Generally, this is not the case with traditional retailing as it requires considerable effort on the part of the customers to move to the process. Since these things are different from each other, these things present different types of aesthetics for the organization and based on this aspect, customers would develop a different perception of each form of retailing.

Lusch et al. (2015) highlighted that Some customers want self-service retail options as in this option they are free to spend as much time as they want in making a purchase decision. This option does not compromise customers' autonomy. Moreover, salesmen cannot influence customers in making any purchase decision. On the contrary, some customers indicated that they are more satisfied if they receive assistance from the salesmen. Such customers report that if they do not have information about a product, for example, a specialty product then customers contact the salesmen and seek their support. This adds convenience to the sales process.

In case of full-service, the salesmen become the part of overall aesthetics of retail store. His language, appearance, mannerisms, tone, etc. would develop an impression of organizational aesthetics on the customers. In case of self-service retail and e-retailers, there are fewer chances of these as there are fewer chances of the interaction of customers with the organization. Likewise, there is less autonomy of customers in full-service retail as salesmen influence overall purchase process whereas, in case of last two levels (self-service and e-retailer), and this is not the case. Thus, it can be argued that in case of fullservice retailing the aesthetics of retailer are different from selfservice and e-retailer.

Škudienè et al. (2013) suggested that while selecting a retail service level, retailers keep the cost of operations in mind. Where self-service requires more space, full-benefit retailing required greater venture to be made in staff. So, while making such decisions, a cost analysis should be carried out and should be used in conjunction with the desired level of value which is to be added by the retailer. Figure 1, 2, 3 and 4 are an indicator that these retailers have different layouts and different space allocations to vegetables and fruits as well as to the people so that they can move in the retail area and select their items. This increases the cost of operations of self-service retailers. Moreover, since in case of self-service retailers, customers have to move around the area, so retailers have to spend money on the décor, cleanliness, lighting, temperature and other aspects of retail space. Consequently, self-service retailers have to spend more attention on the aesthetics of such retail space. Presumably, money spent by eretailer is different from the money spent by the other two types of retailers. E-retailers have to spend money on hosting a website, computer hardware and software and other related aspects. This may not be the case with the traditional retailers.

Further to this, Jie et al. (2015) highlighted the case of variety seeking customers and suggested that such customers prefer website and phone retailers. It can be seen that aesthetics of three types of retailers differ from each other. In case of e-retailer, it is perhaps the easiest as customers can sort and find things with just a few clicks. However, this is not the case with other options. In case of full-service retailing, the customer has to ask the retailer. If the retailer is busy in other things, he may not be able to give lots of time to the customer. So generally, the speed of services is more in case of full-service retailers. On the contrary, customers can spend as much time as they want on self-service and e-retailing so it generally takes more time in these two options.

Jie et al. (2015) suggested that online retailers can use audio, video and multimedia options while making any purchase decision. The websites have built-in scripts, which provide such multimedia environment to their customers or even site visitors. Self-service retailers can provide similar options as customers use to spend considerable time in the retail outlet. Full-service retailers may also provide similar audio-video facilities but these are of limited use for the customers.

Kumar (2014) suggested that in case of full-service options, customers do not have many opportunities of interacting with fellow customers or other persons and seek guidance for making a purchase decision. In case of a full-service retailer, there is the limited opportunity of doing so as retailer tends to finish transaction processing at his earliest and in an attempt to do so he prefers that customers do everything as quickly as possible related to the transaction. However, this is not the case with the self-service retailer and even e-retailers. In both cases, there is considerable time for the customers to discuss transaction processing with other fellow customers. The layout aesthetics is designed in a manner that customers can move around in the retail area freely and can meet with other fellow customers. Likewise, in case of e-retailers, customers can read the product/service reviews or product/service rating of old customers. This is similar to discussing with other customers about the product/services. The aesthetics of both layouts has implications on the purchase process. This can be seen in figure 6 which is given below.

\section{Fig. 6. Self-Service Retailer}

Kumar (2014) further highlighted that in case of online retailing, customers can not touch, smell and feel the products. They can see the pictures of the products. There are chances that actual products may differ from the products which are displayed on the website. Next in line is the full-service retailer where retailer selects and puts products in the shopping bag. In this case, customers can see products yet and customers can feel and smell products once they receive the products from retailers. From this perspective, the best option is self-service retailing in which customers can touch, feel, smell and even taste those. Customers can spend as much time as they want in the retail area and select products and service of their choice.

Foster and Resnick (2013) added to merits and demerits of different level of retail service level and suggested that in case of self-service retailing in a store, the speed of service is generally slow. However, if customers obtain the assistance of retailer or his staff then the transaction can be quickly processed. This would help customers in 
obtaining desired products quickly. In all three forms of retailing service level, customers can interact with the retailer. However, this interaction varies for each service level. In case of e-retailer, websites provide links for chatting with customers. Likewise, customers of self-service retailing can always go to Customers' Service Counter and can request information. Lastly, in case of full-service retailing, the customer can have maximum interaction with the retailer as retailer leads the transaction. Where online retailing has its pros and cons, the greatest challenge lies with the customer as only those customer who have access to the internet, must know how to use it and have the related facilities for using it. This is not the case with full-service and self-service retailing of vegetables and fruits through the traditional retail channel.

\section{Conclusion and future research areas}

$\mathrm{OA}$ is emerging as a new area of organizational study and it is a form of human knowledge which a person develops by using his five senses i.e., hearing, sight, touch, taste, and smell. OA as a field of study, helps concerned people put themselves within a broader social context. It is an influential technique through which an organization can manipulate its image in the eyes of its stakeholders including its customers and employees. OA is not merely associated with making workplace beautiful rather it can be used to manipulate organizational power over its stakeholders. In an attempt to influence customers, the organization makes considerable attempts related to OA. An evaluation of conceived and perceived space is important so that one can evaluate whether conceived and perceived spaces of organizational aesthetics are same or not. Organizational image and reputation is a critical ingredient of organizational success. It is associated with feelings of buyers about the organization and its related aspects. One such factor which shapes buyers' perception about the organization, is the retailing strategy of the organization. If the product image is tarnished, sales and profits of organization will decreases. It is, therefore, the responsibility of the organizational decision makers that they should develop and maintain such retailing strategy that customers receive requisite value from the organization. In this regard, efforts should be made to develop a quality image of the organization and its products and services. The aim of this research is to evaluate aesthetics of different service level of retailers of convenience products. Such an evaluation of aesthetics of retailers based on service level would become the basis of evaluation of how each option generates value for the customers. Such knowledge will be useful for the organizational decision makers and they can utilize it to select/adjust service level with the desired level of value. The findings of the research revealed aesthetics of different types of retailers (full-service, self-service, and e-retailer). The style of these three diverse retail levels differ in view of format of retail outlet, accommodation-related with each type of outlet, cleanliness, basic leadership process, impact of salespeople, self-sufficiency of purchaser in choosing items/administrations, cost of operations to retailer, speed of administration, assortment looking of conduct, music, sound and video in retail condition, capacity to counsel others, chance to feel items, level of training, chance to retailer of collaboration and gaining from clients and shopping at claim speed. Retailers should choose their retailing methodology (self-benefit retailing, full-benefit retailing and e-retailer) after a watchful examination of these elements.

This research has few limitations. To start with, data for this research paper was collected using qualitative research techniques so limitations of qualitative research apply to this research. Moreover, sample selected for this research was not very large. Had a larger sample being selected for this research then it would have been better. Likewise, selection of organizations and respondents was based on the judgment of researchers. This was prone to researchers' biases. Findings of this research are related to fruits and vegetables only. These are only two products, which are offered by the retailer and cannot be generalized on remaining items of retail stores.

Future researchers should overcome the limitations of this research and test the concept so that findings of this research can be confirmed.
This research project is only related to fruits and vegetables. It is suggested that future researchers should look at other products offered by a retail store and confirm whether findings of this research are applicable to other products as well. The data for this research was based on interviews and observation. It is suggested that future research should be based on the survey so that a larger group of respondents can be selected and data can be collected from these respondents.

\section{References}

Berg, P. O., \& Kreiner, K. (1990). Corporate architecture: Turning physical settings into symbolic resources. Symbols and artifacts: Views of the corporate landscape, 41, 67.

Broyles, S. A., Ross, R. H., Davis, D., \& Leingpibul, T. (2011). Customers' comparative loyalty to retail and manufacturer brands. Journal of Product \& Brand Management, 20(3), 205-215.

Cazzato, D., Leo, M., Spagnolo, P., \& Distante, C. (2014). Pervasive Retail Strategy Using a Low-Cost Free Gaze Estimation System Video Analytics for Audience Measurement (pp. 23-39): Springer.

Dickinson, P. (2000). Beautiful corporations: Corporate style in action: Financial Times Management.

Dzidowski, A. (2015). New and Speculative Organisational Aesthetics. Organizational Aesthetics, 4(1), 19-31.

Foster, C., \& Resnick, S. (2013). Service worker appearance and the retail service encounter: the influence of gender and age. The Service Industries Journal, 33(2), 236-247.

Gagliardi, P. (1990). Artifacts as pathways and remains of organizational life. Symbols and artifacts: Views of the corporate landscape, 3-38.

Hancock, P. (2005). Uncovering the semiotic in organizational aesthetics. Organization, 12(1), 29-50.

Henley, N., \& Patrick, D. (1977). Body politics: Power, sex, and nonverbal communication: Prentice-Hall Englewood Cliffs, NJ.

$\mathrm{Hu}, \mathrm{W} .$, \& Li, Y. (2012). Retail service for mixed retail and E-tail channels. Annals of operations Research, 192(1), 151-171.

Jie, Y. U., Subramanian, N., Ning, K., \& Edwards, D. (2015). Product delivery service provider selection and customer satisfaction in the era of internet of things: A Chinese e-retailers' perspective. International Journal of production economics, 159, 104-116.

Kumar, R. (2014). The impact of pricing strategy in retail sector. International Journal of Marketing and Technology, 4(4), 161-174.

Lefebvre, H. (1991). The Production of Space: Blackwell, Oxford, UK.

Lin, Z., \& He, X. (2015). The images of foreign versus domestic retailer brands in China: A model of corporate brand image and store image. Journal of Brand Management, 22(3), 211-228.

Long, M., \& McMellon, C. (2004). Exploring the determinants of retail service quality on the Internet. Journal of Services Marketing, 18(1), 78-90.

Lu, Y., \& Seo, H.-B. (2015). Developing visibility analysis for a retail store: a pilot study in a bookstore. Environment and Planning B: Planning and Design, 42(1), 95-109.

Lusch, R. F., Serpkenci, R. R., \& Orvis, B. T. (2015). Determinants of retail store performance: a partial examination of selected elements of retailer conduct. Paper presented at the Proceedings of the 1995 World Marketing Congress.

Macintosh, G., \& Lockshin, L. S. (1997). Retail relationships and store loyalty: a multi-level perspective. International Journal of Research in marketing, 14(5), 487-497.

Magala, S., Weggeman, M., Lammers, I., \& Akkermans, H. (2007). Aesthetics from a design perspective. Journal of Organizational Change Management, 20(3), 346-358.

Maxwell, J. A. (2012). Qualitative Research Design: An Interactive Approach: An Interactive Approach: SAGE Publications.

McLeod, K., \& Guillemin, M. (2016). Adding the agentic capacities of visual materials to visual research ethics. Visual Methodologies, 3(2), 27-42.

Naylor, G., \& Frank, K. E. (2000). The impact of retail sales force responsiveness on consumers' perceptions of value. Journal of Services Marketing, 14(4), 310-322.

Pratt, M. G., \& Rafaeli, A. (2006). Artifacts and organizations: Beyond mere symbolism: Lawrence Erlbaum Associates Pub.

Samli, A. C. (2015). Retail Marketing Strategy Development Coping with Retail Giants (pp. 17-25): Springer.

Schön, D. A. (1983). The reflective practitioner: How professionals think in action Basic books. New York.

Škudienė, V., Everhart, D. D., Šlepikaitė, K., \& Reardon, J. (2013). Front-Line Employees' Recognition And Empowerment Effect On Retail Bank Customers' Perceived Value. Journal of Service Science (JSS), 6(1), 105116. 
Strati, A. (2015). Aesthetics and design. The Routledge Companion to Philosophy in Organization Studies, 251.

Taylor, S. S. (2016). Seeing More or Seeing Less. Organizational Aesthetics, $5(2), 1-2$

Taylor, S. S., \& Hansen, H. (2005). Finding form: Looking at the field of organizational aesthetics. Journal of Management Studies, 42(6), 12111231.

Taylor, S. S., \& Ladkin, D. (2009). Understanding arts-based methods in managerial development. Academy of Management Learning \& Education, 8(1), 55-69.

Turley, L. W., \& Chebat, J.-C. (2002). Linking retail strategy, atmospheric design and shopping behaviour. Journal of Marketing Management, 18(12), 125-144.

Wan, W. P., Chen, H. S., \& Yiu, D. W. (2015). Organizational Image, Identity, and International Divestment: A Theoretical Examination. Global Strategy Journal, 5(3), 205-222.
Wasserman, V., \& Frenkel, M. (2015). Spatial work in between glass ceilings and glass walls: Gender-class intersectionality and organizational aesthetics. Organization Studies, 36(11), 1485-1505.

Witkin, R. W. (1990). The aesthetic imperative of a rational-technical machinery: A study in organizational control through the design of artifacts. Symbols and artifacts: Views of the corporate landscape, 325338.

Wong, A., \& Sohal, A. (2003). Service quality and customer loyalty perspectives on two levels of retail relationships. Journal of Services Marketing, 17(5), 495-513.

Wu, W.-Y., Lee, C.-L., Fu, C.-S., \& Wang, H.-C. (2013). How can online store layout design and atmosphere influence consumer shopping intention on a website? International Journal of Retail \& Distribution Management, 42(1), 4-24.

Yildirim, K., Cagatay, K., Hidayetoglu, L. M., \& Towers, N. (2015). The effect of age, gender and education level on customer evaluations of retail furniture store atmospheric attributes. International Journal of Retail \& Distribution Management, 43(8), 17-24. 